$\begin{array}{llll}\text { Submitted } & : \mathbf{2 4 . 0 9 . 2 0 2 0} & \\ \text { Accepted: } & : \mathbf{1 5 . 1 2 . 2 0 2 0} & \\ \text { Year } & : \text { July } 2020 \quad \text { Volume: } 1 \quad \text { Issue: } 1 \\ \text { DOI } & : \mathbf{1 0 . 4 7 3 3 3 / m o d e r n i z m . 2 0 2 0 1 6 5 1 1 2}\end{array}$

\title{
DECONSTRUCTION AND TURGENEV'S FATHERS AND SONS
}

Victoria Bilge Yılmaz ${ }^{1}$

\begin{abstract}
World literature underwent a drastic turn with the emergence of the philosophy of Jacques Derrida, particularly with the emergence of the concept of deconstruction. Although Derrida used the concept of deconstruction in terms of philosophical ideas, the emergence of this concept paved the way for different interpretations of literary texts. Deconstructing a text means using the text's own structure to subvert the meaning the text tries to convey. It might be said that the concept of deconstruction as it is employed in literature seeks the ways to lay bare the mechanisms behind the constructions of a text. Turgenev's Fathers and Sons (1859) - the novel depicting the struggle between the cultural heritage and the innovative age - presents Bazarov as the representative of the latter; Bazarov stands for stability and certainty that were brought to human beings' existence by the advance of positive sciences. A deconstructive approach to the novel shows that even though the protagonist tries to apply his belief in reason in his life, he fails because the centre on which he relies does not exist as a transcendental signified. Derridean approach to this text unveils the fact that although people of the $19^{\text {th }}$ century celebrated the advance of science and saw it as their new stability, they were mistaken because clinging to one centre is against human nature. They wanted to feel that they were surrounded by the boundaries of the centre but the outside of this centre made itself heard in the instincts of human beings.
\end{abstract}

Keywords: Derrida, Deconstruction, Turgenev, Fathers and Sons, Bazarov.

\section{Introduction}

The link between philosophy and literature is quite strong since both are closely related to life and try to explain its mechanisms. Literature without philosophy would be dry and dull because philosophy grants literature grounds to depict human beings' question of existence. There are many works which are analysed against the background of philosophical ideas. To illustrate, Iris Murdoch's works reflect many philosophical themes; Bernard Shaw was greatly influenced by Nietzsche. Each philosophical question or concept is worked on in literary works by various authors. For instance, Jacques Derrida and his deconstruction theory added to the flow of philosophy a new colour and have greatly affected literature and literary criticism. This study is going to give a brief explanation of Derrida's deconstruction theory and analyse the work of a famous Russian novelist Ivan Turgenev, Fathers and Sons (1859), under the light of deconstruction.

\section{Jacques Derrida and Deconstruction}

Derrida's philosophy mainly focuses on the explanations of existence in terms of a lack of a centre and awareness of the inability to separate opposite poles, binary oppositions. Firstly, let's have a look at what a centre means in Derridean philosophy. Derrida explains the centre as the power that seems to control any kind of deviation:

The function of this centre was not only to orient, balance, and organise the structure - one cannot in fact conceive of an organised structure - but above all to make sure that the organising principle of the structure would limit what we might call the play of the structure. (Derrida, "Structure" 176)

Although Derrida does not believe in the idea that a stable organised structure is possible, he defines the centre as this organised structure's control panel. Thought from a literary point of view, this brings us to the idea that every word is supposed to have its stable meaning. In philosophical

\footnotetext{
1 Dr., School of Foreign Languages, Ankara Yıldırım Beyazit University, vikelay@gmail.com, https://orcid.org/0000-0002-9807-9233.
} 
terms, a signifier is bound to its stable signified, which means that there is only one meaning of a word. This organised structure can also be referred to as logos; it is a belief or an idea that everything is strictly linked to its referent and that everything is under control. What Derrida rejects is precisely this notion of a centre. He states that the signified is not actually a stable referent but just another signifier, which means that there is an infinite number of signifiers: "The absence of the transcendental signified extends the domain and the play of signification infinitely" (Derrida "Structure" 178). This belief brings such notions like democracy, freedom, truth, religion or ideology into discredit because they are also seen as just signifiers. In other words, they lack their stable meaning and can change from occasion to occasion. Derrida calls this lack of signified différance. The term différance shows two meanings: one is to "differ" and the other is to "defer". The meaning of the signifiers can always change and at the same time, reaching the meaning of a signifier can always be delayed. In other words, signifiers remain unspecified in terms of meaning. Indeed, Derrida uses the term différance to "show how language depends on differential systems to produce meaning while at the same time endlessly postponing a final end to this production" (Booker 63).

As a result of Derrida's rejection of the notion of a centre, the concept of logocentrism becomes open to doubt. Roughly explained, logocentrism is set of beliefs according to which universe and existence, in general, are based on stability, certainty and neat categorisations. Habib explains the term différance and the shattering of logocentrism with an example about religion:

In this sense, the concept of God moves from being a reality beyond language to a concept within language: it becomes discourse. And the systems of thought that depended on the understanding of God as a reality become "decentred", losing their former stability and authority. (Habib 656)

The concept of God that was regarded as the signified, becomes a signifier according to what Derrida and Habib state and it becomes a mere discourse; a mere product of language. Consequently, God is not a centre of existence anymore according to this way of thought.

Another thing that might be said in relation to Derrida's philosophy is his attitude to binary oppositions which he actually transcends. Derrida explains the concept of binary oppositions with the help of Platonic explanation of existence. According to the Platonic view of existence, there is a realm of Forms - an ideal transcendental being - and the world of shadows to which human beings belong or to which signifiers belong. According to Derrida, Platonic explanation of existence is trapped in the idea of binary oppositions. Richard Rorty explains what binary oppositions are in this context:

The characteristic expressions of this other-worldliness, this attempt to escape from time and history into eternity, are what deconstructionists often call 'the traditional binary oppositions': true-false, original-derivative, unified-diverse, objectivesubjective, and so on. (Rorty 169)

In other words, the belief in the presence of a signified, a God, or Platonic Forms brings with it the concept of binary oppositions, which, in turn, generate more examples of opposition. For example, it can be said in this regard that Platonic Forms and the world of shadows are binary oppositions. The realm of God and the physical world of human beings are binary oppositions. Because Derrida rejects the idea of the centre, he rejects the concept of binary oppositions. Booker argues that according to Derrida, binary oppositions are not contrary to each other but "mutually involved". He adds that Derrida even accepts the impossibility of conceiving these oppositions independently (Booker 60). For Derrida, in fact, as it was mentioned above, there are only signifiers and this belief discredits any kind of binary oppositions.

\section{Deconstruction and Literature}

The emergence of the philosophy of Jacques Derrida influenced world literature and literary criticism to a great extent. The term deconstruction was used as an umbrella for various kinds of interpretations of texts by the critics who approached a text in terms of Derridean philosophical thoughts. Although Derrida used the concept of deconstruction to explain some philosophical issues, his ideas paved the way for a different kind of interpreting literary texts. The only strategy to deconstruct is to follow the structure of the deconstructed object. The deconstructed object provides its unique techniques of deconstruction, though not consciously. In other words, the technique to 
deconstruct an object, in our case it is a literary text, differs from object to object. Thus, it is not possible to create a stable set of techniques of deconstruction. In this regard, Derrida states:

The movements of deconstruction do not destroy structures from the outside. They are not possible and effective, nor can they take accurate aim, except by inhabiting those structures. Inhabiting them in a certain way, because one always inhabits, and all the more when one does not suspect it. Operating necessarily from the inside, borrowing all the strategic and economic resources of subversion from the old structure, borrowing them structurally, that is to say without being able to isolate their elements and atoms, the enterprise of deconstruction always in a certain way falls prey to its own work. (Derrida, Grammatology 24)

In this way, the technique of deconstruction itself becomes a kind of signifier that changes its meaning from object to object.

A deconstructive interpreting of a text seeks the ways to lay bare the mechanisms behind the construction of a text and then find out the elements in a text that contradict the purpose of those mechanisms. Habib explains this way of reading a text thus:
A deconstructive reading of a text, then, as practiced by Derrida, will be a multifaceted project: in general, it will attempt to display logocentric operations in the text, by focusing on a close reading of the text's language, its use of presuppositions or transcendental signifieds, its reliance on binary oppositions, its self-contradictions, its aporiai or points of conceptual impasse, and the ways in which it effects closure and resists free play. Hence deconstruction, true to its name, will examine all of the features that went into the construction of text, down to its very foundations. (Habib 654)

During a deconstructive reading of a text, one will find out the text's supposed meaning, the idea it tries to convey. Only then, a deconstructive critic will try to observe the ways in which the text contradicts its own messages and mechanisms. Deconstructing a text, in other words, means to reveal its contradictions enveloped in the language it uses. Rorty observes that "[a]s used by members of this school, the term 'deconstruction', refers in the first instance to the way in which the 'accidental' features of a text can be seen as betraying, subverting, its purportedly 'essential message" (171). After a deconstructed interpretation of a text, it becomes obvious that a text lacks a centre that it claims to have. In other words, while a text tries to prove that a particular idea exists in it, it, in fact, proves right the opposite - that this idea does not exist there at all. Thus, a deconstructive interpretation of a text reveals a text's failure to convey a certain meaning, but it does not attempt to mitigate that failure. As Booker states, through the language in the text deconstructionists unearth "irony, ambiguity, paradox, and other forms of multiple meanings", but refuse to solve them (Booker 56).

It should not be forgotten that language is a significant element that deconstructionists work with during a deconstructive interpretation of a text. Indeed, it is so because language is the main channel through which the belief in logocentrism is conveyed to the reader. Booker goes deeply in this issue and explains it thus:
Derrida notes that logocentric logic sees language as a reflection of some pre- existing meaning or reality, whereas he believes that meaning is created in language.
.. [J]ust as Derrida sees no clear boundary between text and context, he also sees no absolute distinction between subject and world. . . For Derrida . . . the human subject is created in and through language rather than existing prior to and independently of language. (57)

From a logocentric point of view, language refers to something transcendent, the signified. Thus, in this view, language is the signifier. Derrida, on the contrary, believes that language is the source itself. It is precisely the language itself that creates meaning. Thus, language and meaning, or the signified, to use the logocentric terms, belong to one body in Derridean approach. Nothing is beyond language; language does not refer to a signified, it refers to itself. As a result, deconstructionists analyse the language in a text, lay bare the mechanisms that the language constructs, and then find the points where language fails to convey the expected message. 
As regards the relationship between Russian literature and the concept of deconstruction, it can be argued that there are a few works that analyse texts from a deconstructive point of view. In his book Deconstruction and Classical Russian Literature (2005), Andrey Sherbenok discusses four major Russian authors in terms of deconstruction and post-structuralism. In 2017, Sevgi Ilica studied Pushkin's poem in terms of deconstruction in her article "Deconstruction and a Deconstructive Reading of Alexander Sergeyevich Pushkin's The Fountain of Bakhchisaray". There are a few studies on recent authors' works. For example, in her article "The Deconstruction of Representation in Vladimir Sorokin's Short Stories" (2006), Eleonora Morelli studies Sorokin's short stories in a deconstructivist approach. Sun Haiying analyses Bulgakov's The Master and Margarita in an article "Deconstruction of Utopia: Contrast Analysis of Collective Unconsciousness in Chevengur and The Master and Margarita" (2014). In fact, although there are some valuable works that analyse some Russian literary texts in terms of deconstruction, still there is a significant gap in this field. This study is going to contribute to bridge this gap and provide some insight into the relationship between deconstruction and Russian literature.

\section{Deconstructing Turgenev's Fathers and Sons}

Having written his Fathers and Sons in 1859, Turgenev was scathingly criticised for his socalled unfair observation of the gap between two generations. Turgenev was accused of depicting the older generation paralysed in their ignorance and decay and of exhibiting the younger generation quite critical of their fathers. These critics might be right in their concerns; yet, what should be noticed is the idea that neither the older generation nor the younger one gets any endorsement from the author. Lebedev expresses a similar idea thus:

There should be a balance: Pavel Petrovich stresses conventions and damns individualism, Bazarov stresses individualism and damns all the authorities. Truth escapes both; Kirsanov does not show fatherly affection and Bazarov fails to depict respect of a son. (Lebedev 438)

Neither fathers' principles nor sons' materialism leads to truth. Both sides fail in their struggle to establish their authority over the other. In general, the novel is about a nihilist and a materialist young physician, Bazarov, who rejects all authorities. Bazarov goes to his friend Arkady Kirsanov's province to spend some time with the Kirsanovs. During his stay in this province, Bazarov desperately falls in love with Madame Odintsov, but does not get any response. He eventually contracts typhus while performing an autopsy and dies. The novel depicts Bazarov as a nihilist and a materialist. However, a deconstructive approach to the novel reveals some of Bazarov's characteristics or behaviours that cannot be regarded as nihilistic or materialistic. Although Bazarov tries to depict himself as a man for whom everything should have a reason and purpose, his behaviour unearths his tendency to experience irrationality. The rest of the paper is going to unveil Bazarov's inability to completely cling to the principles of nihilism and materialism. After analysing Bazarov's ways of approaching everything around him, this study will go on by revealing his failures to do so.

To begin with, Bazarov claims to be against everything that cannot be explained by reason. From a Derridean point of view, the reason is the centre for Bazarov. For example, nature is very simple and lacks variety for Bazarov. It is as simple as seeing human beings similar to frogs. For example, when Bazarov goes out to collect frogs in order to analyse their inside, he talks to some boys who help him: "You and I are frogs too, except that we walk upon our hind legs" (Turgenev 19). Obviously, Bazarov tends to categorise everything according to the physical attributes. Being a materialist, Bazarov makes himself believe in the idea that everything can be studied just by analysing one sample of each species:

'In the first place', he retorted, 'the prime requisite in that connection is experience of life; and, in the second place, the study of detached personalities is scarcely worth the trouble. For all we human beings are alike, in body as in spirit. In each of us there is an identical brain, an identical spleen, an identical heart, an identical pair of lungs, an identical stock of the so-called moral qualities (trifling variations between which we need not take into account). Therefore from a single specimen of the human race may all the rest be judged. In fact, human beings are like trees in a forest. You never find a botanist studying its individual trunks.' (Turgenev 82) 
He disregards the inner world of human beings that embraces feelings such as love, affection, or hatred which deconstructionists would affirm as the elements that escape centrality. Moreover, Bazarov rejects the notion of love and tries to show that there is no place for the mystery of love in a human being's physical body:

For of what do the so-called mysterious relations between a man and a woman consist? As physiologists, we know precisely of what they consist. And take the anatomy of the eye. What in it justifies the guesswork whereof you speak? Such talk is so much Romanticism and nonsense and unsoundness and artificiality. Let us go and inspect that beetle. (33)

His attitude towards feelings is quite straight forward as he just thinks that they do not exist in a physical body. In a way, from a deconstructionist's point of view, Bazarov's signified to which he tries to cling is materialism. He thinks everything can be explained rationally and logically. Although he is interested in women's physical bodies, he maintains that he is shielded from deep senses: " $[\mathrm{H}] \mathrm{e}$ looked upon love in the ideal, the 'romantic' (to use his own term) aspect as unpardonable folly, and upon the sentiment of chivalry as a sort of aberration or malady" (Turgenev 91). Nature, or the world, in general, is a kind of an experimental environment: "Nature is rubbish - at least in the sense in which you understand her. She is not a church, but a workshop wherein man is the labourer"' (Turgenev 43). Bazarov even rejects art and becomes surprised when hears Nikolai, Arkady's father, play the cello. According to Woodward, Bazarov approaches playing the cello as something absurd because of his "utilitarian creed" (125). Surely, an activity of playing an instrument, which is usually loaded with feelings and which often evokes emotions, should be accepted as something irrational by a person whose only way of perception of everything is through reason.

Secondly, Bazarov does not accept romanticism. At the beginning of the novel, Arkady's father, Nikolai Petrovitch quotes some lines from Pushkin:

'Yes; specially for your homecoming is spring in all its glory. Yet I am not sure that I do not agree with Pushkin where he says in Eugene Onegin:

How sad to me is your coming,

O spring, spring, season of love!'

'Arkady,' shouted Bazarov from the tarantass, 'please send me a match or two, for I have nothing to light my pipe with.' (Turgenev 13)

On hearing some romantic lines from a poem, Bazarov is quick to interrupt Nikolay's romantic speech and offers smoking. Later on, Bazarov openly states that he is against romanticism: "Your father, too, is excellent; for though he may read foolish poetry, and though his ideas on the subject of industry may be few, his heart is in the right place" (Turgenev 17). Actually, for Bazarov the fathers are just "elderly Romantics" (Turgenev 18) whose view of life he rejects. When he converses with Paul Petrovitch, Nikolay's brother, he even states that "[a] good chemist is worth a score of your poets" (Turgenev 26). Bazarov's attitude to poets in general shows his choice of seeing a human existence through a physical body's existence only. It might be even argued that poets who deal with the production of irrational collection of words cannot constitute one so-called rational physician.

Despite all these obvious manifestations of a materialist person, it is not difficult to see that Bazarov's materialism is not as strong as he wants to show. It is not possible to easily pin him down to his centre marked by materialism and utilitarianism. Waliszewski pinpoints Bazarov's contradictory nature:

Bazarov is a very clever man, but clever in thought, and especially in word, only. He scorns art, women, and family life. He does not know what the point of honour means. He is a cynic in his love affairs, and indifferent in his friendships. He has no respect even for paternal tenderness, but he is full of contradictions, even to the extent of fighting a duel about nothing at all, and sacrificing his life for the first peasant he meets. (Waliszewski 285) 
For example, despite all his hatred towards romanticism and poetry, he falls in love. The object of his love is Madame Odintsov whose characterisation also suggests contradictions:

\begin{abstract}
And she too was a strange being. Free from all prejudice, and devoid of all strong beliefs, she rendered obeisance to nothing, and had in view no goal. Again, though much was open to her sight, and much interested her, nothing really satisfied her, and she had no wish for such satisfaction, since her intellect was at once enquiring and indifferent, and harboured doubts which never merged into insensibility, and aspirations which never swelled into unrest. . . Again, like all women who have never known what it is to fall in love, she was sensible of a persistent yearning for something wholly undefined. There was nothing that she actually lacked, yet she seemed to lack everything. (Turgenev 86-87)
\end{abstract}

Even the passage above that tells about Madame Odintsov is a meaningless collection of words which suits the characterisation it depicts. Bazarov's choice of a woman with whom to fall in love with specifies his subconscious tendency to resist materialism and embrace irrationality. "Turgenev confronts his materialist and rationalist with a woman who stands as a challenge incarnate to the naive proposition that "two and two make four'" (Woodward 127). In fact, as Lebedev argues, the reason behind Bazarov's harsh attack on poetry, love and philosophy is his desire to conceal his true attitude towards these notions; he knows that he is prone to feelings that cannot be described by any doctrine (Lebedev 438). Phelps discusses Bazarov's love to Madame Odintsov thus:

To Bazarov, women were all alike, and valuable for only one thing; he had told this very woman that people were like trees in a forest; no botanist would think of studying an individual birch tree. Why, then, should this entirely unimportant individual woman change his whole nature, paralyse all his ambitions, ruin all the cheerful energy of his active mind? He fights against this obsession like a nervous patient struggling with a dreadful depression that comes over him like a flood. He fights like a man fighting with an enemy in the dark, whom he cannot see, but whose terrible blows rain on his face. (Phelps 105)

Bazarov, who does not accept the idea that each person has his/her individual characteristics, starts to change in this regard and even pronounces this statement when he talks to Madame Odinstov: "You may be right. Possibly every human being is an enigma" (Turgenev 95). Bazarov's inexplicable feelings towards Madame Odintsov make him believe in enigmas. Because of his love to Madame Odintsov, says Lebedev, Bazarov is fragmented into two; one is a nihilist who rejects all the principles and the other part is a man who is in love with a woman (442). Even when he meets Madame Odintsov for the first time, Bazarov feels different. Arkady notices this difference in his friend when Madame Odintsov invites them to visit her: "Bazarov merely bowed: which again surprised Arkady while also he noticed that his friend's face looked flushed" (Turgenev 77). Bazarov even starts to believe in superstitions. When Bazarov and Arkady go to their room, the former says: "Congratulate me!' cried Bazarov of a sudden. 'Today is the $22^{\text {nd }}$ of June - the feast of my Patron Saint. Certainly he looks after me, does he not?'” (Turgenev 78) Bazarov's knowledge of natural sciences used to provide him with a stable background onto which he depended. Yet, being aware of the loss of this background, Bazarov tries to find out a new one. As Lebedev concludes, Bazarov loses his optimism and certainty after acknowledging his feelings to this woman (Lebedev 445). Thus, it is not possible to approach Bazarov-in-love as a totally materialistic character.

Another example from which it is possible to see that Bazarov is not a person whom he wants to seem is related to his family relationships. Although he criticises the older generation and restrains from showing his love to them, sometimes he fails to do so. For example, when he is in his parents' home he becomes bored and wants to leave but is afraid of upsetting his mother and father. He does not want them to be upset because of his absence. At the beginning, he says to Arkady that it does not matter to him whether his parents will be upset or not, but in truth, it was important for him: "Yet, though Bazarov had said 'No matter,' he let the whole of the rest of the day elapse before he could make up his mind to acquaint Vasili Ivanitch with his intention" (Turgenev 132). He becomes quite sensitive towards his parents, which, indeed, he cannot control. He falls prey to uncontrollable forces of a human being. 
Even the cold-hearted Bazarov is shaken by the joy of his mother's greeting when he returns home, and by her agony at his early departure. He hates himself for not being able to respond to her demonstrations of affection. Unlike most sons, he is clever enough to understand the slavish adoration of his parents; but he realises that he cannot, especially in the presence of his college friend, relieve their starving hearts. (Phelps 108)

In fact, Bazarov is aware of his inability to show his emotions to his parents, but does not want to reveal his feelings. Lebedev states that Turgenev's nihilist keeps all the things that he rejects: love, romanticism, national feelings, family relations, and ability to value beauty and poetry (Lebedev 438). These things that Bazarov seems to reject, but keeps, in fact, do not belong to the rational side of a human being. On the contrary, they dismantle logic and get rid of it because they belong to the realm of human instincts which are uncontrollable.

Although Bazarov is against poetry, there are scenes when he uses poetic language. For example, when he dies and when Madame Odintsov comes to visit him, he says: "O woman of kind heart! .. A Ah, breathe now upon the expiring lamp, that it may go out in peace. . . Now let there come - darkness" (Turgenev 194). His poetic words refer to many things which defy any stable signified. Bazarov abandons his rational self. He used to believe in the greatness of a man: "Bazarov, like the radicals whose views he reflects, sees man himself as the maker of his destiny" (Woodward 124). He used to think that a human being can do everything; he can even draw his fate. Yet, he gives these ideas up. When he talks to Madame Odintsov, he pronounces the statements which defy his previous beliefs: "Can it avail anything to discuss the future when, for the most part, our futures are wholly independent of ourselves?" (Turgenev 101) Bazarov accepts the arbitrariness and uncertainty of life; he sees that life is independent of human beings' strenuous efforts to control it. What is more, he falls prey to death, to that irrational and inevitable end. In his deathbed he says to Madame Odintsov:

Of all things in this world long life is the most desirable: yet you can see for yourself what an ugly spectacle I, a half-crushed, but still wriggling, worm, am now become. There was a time when I used to say: "I will do many things in life, and refuse to die before I have completed those tasks, for I am a giant": but now I have indeed a giant's task in hand - the task of dying as though death were nothing to me. (Turgenev 194)

For Bazarov, being alive used to be something that he could easily control. Yet, he could not grasp the slippery reality of everyday existence. Turgenev beautifully portrays Bazarov's decline and the language of the text reveals the impossibility of fixing life. Woodward summarises Bazarov's characterisation when he states that Bazarov is portrayed as a materialist with a limited, simplified view of reality. He is a ceaseless, rootless traveller lacking 'firm ground' beneath his feet and is shown in the end to be 'superfluous':

His challenge is taken up by the life that he rejects. The rationalist who declares that 'two and two make four' and insists that 'everything else is trivial' (p. 236) is confronted with 'trivialities' that he cannot reject, with irrational mysteries that elude his scalpel, with the power of beauty and the power of death, and in the end he is ironically made to capitulate to the main 'imperfection' that he sought to eliminate. (Woodward 125)

In other words, Bazarov, who used to believe in the greatness of man and disregard any notion of chance in human existence, loses in the card-games twice. Firstly, he loses to Madame Odintsov and then to the priest in his parents' home. So, Bazarov cannot master his irrational self because he cannot control his feelings and he falls in love. Then he cannot control his life that is lost to death because of a trivial mistake. The ideas that he wanted to reject become his masters; he becomes a toy in their hands. Bazarov admits his defeat and it is obvious when he says: "[T]he infernal thing has come unrolled" (Turgenev 109). The machine driven by reason has fallen apart; not everything can be explained by pure reason. Bazarov becomes a prey in the hands of irrationality. "He is simply obliterated by chance, as an insect perishes under the foot of a passing traveller, who is entirely unaware that he has taken an individual life" (Phelps 104). Bazarov perishes in the darkness of human existence driven by such notions like love, chance and death. 
In conclusion, Turgenev's Fathers and Sons depicts the struggle between the cultural heritage and the innovative age. Bazarov - the representative of the latter - stands for stability and certainty that were brought to human beings' existence by the advance of positive sciences. Although the development of science came against such notions like religion and superstition, it has the same point of reference as the notions it was trying to destabilise. If looked at from a Derridean point of view, religion, superstition, and science strive to have a stable signified to refer to. Thus, Turgenev's novel, in a way, constructs binary oppositions; it is either fathers or sons. A deconstructionist reading of the text shows that these binary oppositions are shattered in the novel because neither fathers nor sons belong to a particular side completely.

This study focused on Bazarov's characterisation, which, according to a deconstructionist approach, does not belong to a particular side. It is a constantly flying signifier that creates as many meanings as possible. Bazarov is presented as a materialist physician; yet, he also shows the signs of a profound lover, a great poet and an ardent lover. In the end, he even becomes a supporter of an idea that life is a great enigma. In fact, Turgenev's text shows that a generation gap is not related to what people usually regard as the difference in age. It is the rejection of differences in life. Accepting the differences and uncertainty, in other words, accepting the existence of signifiers and a lack of a transcendent signified is an ability to see life as it is. Death is also a part of life and Bazarov's death might not be an end; it might be an enigma of life, or just another signifier. The message Fathers and Sons gives is awakening to the fact that the nature of human beings does not accept binary oppositions and that life itself cannot help having an infinite number of signifiers. Life does not have a capacity to host a transcended signified and death itself is just another signifier. Bazarov's death is not his end; it is his delving into the reality of life. His death is the death of materialism and his acceptance of life as it is. Turgenev's message in his novel is not the desired unity of generations; it is the unity of the world and the acceptance of differences. Moreover, Derridean approach to Turgenev's novel unveils the fact that although people of the $19^{\text {th }}$ century celebrated the advance of science and saw it as their new stability, they were mistaken because even at those times human beings could not cling to one centre. They were surrounded by the boundaries of the centre but the outside of this centre made itself heard in the instincts of human beings.

\section{WORKS CITED}

Booker, M. Keith. A Practical Introduction to Literary Theory and Criticism. Longman, 1996.

Derrida, Jacques. Of Grammatology. Baltimore: John Hopkins University Press, 1976.

---. "Structure, Sign, and Play in the Discourse of the Human Sciences". Modern Literary Theory. Philip Rice and Patricia Waugh. London: Arnold, 1996. 176-191.

Habib, M.A. Rafey. "Deconstruction". A History of Literary Criticism and Theory. Oxford: Blackwell Publishing, 2008. 649-666.

Lebedev, Yuriy. "On the Defence of Culture. Novel Fathers and Sons". Turgenev. Moscow: Molodaya Gvardiya, 1990. 434-454.

Phelps, William Lyon. Essays on Russian Novelists. New York: Macmillan, 1911.

Rorty, Richard. "Deconstruction". The Cambridge History of Literary Criticism. Vol. 8. Raman Selden. Cambridge: Cambridge University Press, 1995. 166-196.

Turgenev, Ivan. Fathers and Sons. London: Wordsworth Classics, 2003.

Waliszewski, Kazimierz. History of Russian Literature. New York: D. Appleton and Company, 1900.

Woodward, James. B. Metaphysical Conflict: A Study of the Major Novels of Ivan Turgenev. München, Verlag Otto Sagner, 1990. 